\title{
Converging professional nurses' perceptions and community service nurses' experiences regarding clinical competence during community service placement
}

\author{
K L Matlhaba, ${ }^{1,2} \mathrm{PhD} ;$ A J Pienaar, ${ }^{3} \mathrm{PhD} ; \mathrm{L}$ A Sehularo, ${ }^{1} \mathrm{PhD}$ \\ ${ }^{1}$ School of Nursing Science, Faculty of Health Sciences, North-West University, Mahikeng campus, South Africa \\ ${ }^{2}$ Department of Health Studies, College of Human Sciences, University of South Africa, Pretoria, South Africa \\ ${ }^{3}$ Department of Psychology, School of Health Sciences, University of Venda, Thohoyandou, South Africa; and Department of Graduate Studies and Research, \\ Shifa College of Nursing, Shifa Tameer-e-Millat University, Islamabad, Pakistan
}

Corresponding author: K L Mathaba (matlhkl@unisa.ac.za)

\begin{abstract}
Background. Transitioning from a student to the role of a newly qualified nurse can be difficult when not well prepared. The expectation is that newly qualified nurses should reflect competency across a wide range of skills. To acquire and improve the necessary skills, many countries opted to introduce and implement strategies to prepare nurses for their professional roles. In South Africa (SA), the newly qualified nurse is required to perform an obligatory 12 months' community service as mandated by the regulation promulgated by the Minister of Health.

Objective. To report the convergence results of the perceptions of professional nurses and the experiences of community service nurses (CSNs) regarding clinical competence of the latter during placement in North West Province (NWP), SA.

Method. The study followed a qualitative, explorative, descriptive and contextual design. It employed the World Café data-collection method, including 21 purposively sampled participants. Benner's levels of competence scale was used to rate the competence of CSNs. Pienaar's four steps of qualitative thematic analysis were adapted to analyse data.

Results. Three main themes emerged, i.e. ethos and professional practice; unit management, governance and leadership; and contextual clinical and technical competence.

Conclusion. The World Café method allowed for real conversations around mutual topics of interest, and rich data collected is a true reflection of the participants' perceptions and experiences. These results contributed to the development of a clinical competence evaluation tool for CSNs in NWP.
\end{abstract}

Afr J Health Professions Educ 2020;12(4):191-196. https://doi.org/10.7196/AJHPE.2020. v12i4.1401

The transition from student status to newly qualified nurse can be stressful because of the adjustments to a new role, which requires a combination of knowledge and skills. ${ }^{[1]}$ The stress is due to the notion of being inadequately prepared, lack of confidence and feelings of incompetence. ${ }^{[2]}$ To overcome this, many countries have resorted to the introduction and implementation of methods to improve clinical capabilities of new graduate nurses. In South Africa (SA), the National Department of Health introduced compulsory community service for health professionals in $1998 .{ }^{[3]}$ The primary objective of community service is to enhance quality healthcare access for South Africans, especially in previously under-resourced areas. Young professionals are afforded opportunities, through this process, to develop their skills, establish behaviour patterns and critical thinking and acquire knowledge that assists with their professional development. ${ }^{[3]}$ In 2007, the Nursing Bill was promulgated into the Nursing Act (Act No. 33 of 2005) and, as a result, community service for nurses was effected. ${ }^{[4]}$ The directive stipulates that nurses must complete a mandatory 12-month period of community service after successful completion of the 4-year nursing degree or nursing diploma training (R425) prior to their registration as professional nurses (PNs) (general, psychiatric and community) and midwives. ${ }^{[5]}$ Since the implementation of mandatory community service, numerous researchers have established that community service nurses (CSNs) lack competence in some areas, including basic nursing care, leadership and unit management, teamwork and collaboration, and communication skills, yet there is currently no tool that informs the evaluation of these basic competences. This knowledge gap prompted us to carry out a study of this nature in North West Province (NWP), SA. This article forms part of the original study, which aimed to develop a tool to evaluate clinical competence of CSNs in NWP. Therefore, the objective was to report the convergence of the results of the experiences of CSNs and the perceptions of PNs with regard to the clinical competence of the former during their community service placements.

\section{Definition of competence}

Competence during the Florence Nightingale era was associated with the qualities of the character and skills of a nurse. ${ }^{[6,7]}$ Competence is seen as 'the capacity of individuals to perform the given task. ${ }^{[7]}$ The South African Nursing Council (SANC) defines competence as the 'ability of a practitioner to integrate the professional attributes including, but not limited to, knowledge, skills, judgement, values and beliefs, required to perform as a professional nurse in all situations and practice settings. ${ }^{[5]}$ Therefore, for this study, competence is defined as CSNs' 'ability to function under the legal prescripts, which includes the application of knowledge, psychomotor skills 
and ability to adequately manage the demands that clinical nursing require. ${ }^{[5]}$

\section{Methods}

\section{Research design}

This study used a qualitative, exploratory, descriptive and contextual research design by employing the World Café method to gain a greater comprehension of PNs' perceptions and CSNs' experiences regarding clinical competence for the duration of their placement.

\section{Research setting}

Two tertiary hospitals in the two different regions of NWP were selected. These hospitals were deemed appropriate, as the CSNs were in the second semester of their placement.

\section{Population and sampling}

The study employed a non-probability purposive sampling technique to determine participants subjectively, based on a considered population representation. ${ }^{[8]}$ Purposive samples consist of characteristics based on a particular quality that will benefit the study. In this study, 12 PNs and 9 CSNs attended the World Café. ${ }^{[8]}$

\section{Data collection process}

The World Café method was selected for data collection. It was developed as a brainstorming tool with the aim of creating concepts and explanations of a particular topic. ${ }^{[9]}$ According to Brown and Isaacs, the World Café method is a 'synchronous network of conversations for leading collaborative dialogue, where knowledge is shared; and possibilities for action in groups of all sizes around questions that matter is created. ${ }^{[10]}$ This method was deemed appropriate for the study, as a volume of rich data could be assimilated within a limited period, which prompted ideas and comments from PNs and CSNs on specific topics in the form of questions asked. In applying the World Café principle, an open room was arranged in a manner similar to a café set-up. Four tables with 3 - 4 participants per table convened during data collection, with paper and coloured markers provided to answer the questions. The participants rotated across all the tables. One participant remained at the table to welcome the new group, facilitate their discussions, add to their ideas and capture the responses on the provided paper. Refreshments were served during the process to capture the essence of a café. The process lasted between
15 and 20 minutes, and the following questions were posed during the data-collection process to prompt the World Café discussions:

- Which competencies are needed for CSNs to be regarded as competent practitioners?

- Which competencies are achieved during community service placement? (Use rating scale A and motivate (Fig. 1).)

Each table had a participant who was the host. At the close of each round, the host remained at that table, while the other participants moved to the next table. The host greeted the new group and shared information from the previous group, allowing the new group to familiarise themselves with the written ideas and add new ideas. This process continued until each group of participants had rotated around all the tables and answered all the questions. After the rotation, a final discussion session took place where all the participants reflected on the overall process, and explained and confirmed their results and written ideas.

Fig. 1 depicts the scale used by participants to rate the CSNs' levels of competence for the different competencies mentioned during the first round as they were answering the second question.

Each group was asked to rate their perceived level of competence since the commencement of their community service, using Benner's 5 levels of competence. ${ }^{[11]}$

\section{Data analysis}

Data from the World Café discussions were analysed by the second author and research assistants, following Pienaar's 4 steps (adapted) of qualitative thematic analysis: ${ }^{[12]}$

- Data collection and analysis occurred with basic concepts being derived from the written quotes, which were analysed to identify similar concepts.

- Concepts that emerged were categorised and those that were similar or related were linked together.

- The ratings and motivations were clustered together as additional information that emerged during the process of data collection.

- The pattern was built from themes with ratings and motivations - each theme forming a common background. The first and third authors held a consensus discussion to confirm the final themes.

\section{Trustworthiness}

The following criteria for trustworthiness ensured credibility, dependability, confirmability and transferability: ${ }^{[13]}$

- During data collection, credibility was confirmed in the final discussion, which gave participants the opportunity to review the collected data and provide feedback to each other. Furthermore, the entire process was recorded. Credibility was achieved by interrogation of data by listening to the recordings and reading the transcripts more than once. The researchers immersed themselves in the details to get a sense of the data - co-coding before categorising data into themes and sub-themes.

- Dependability was ensured by the second author as a co-coder. Both researchers analysed

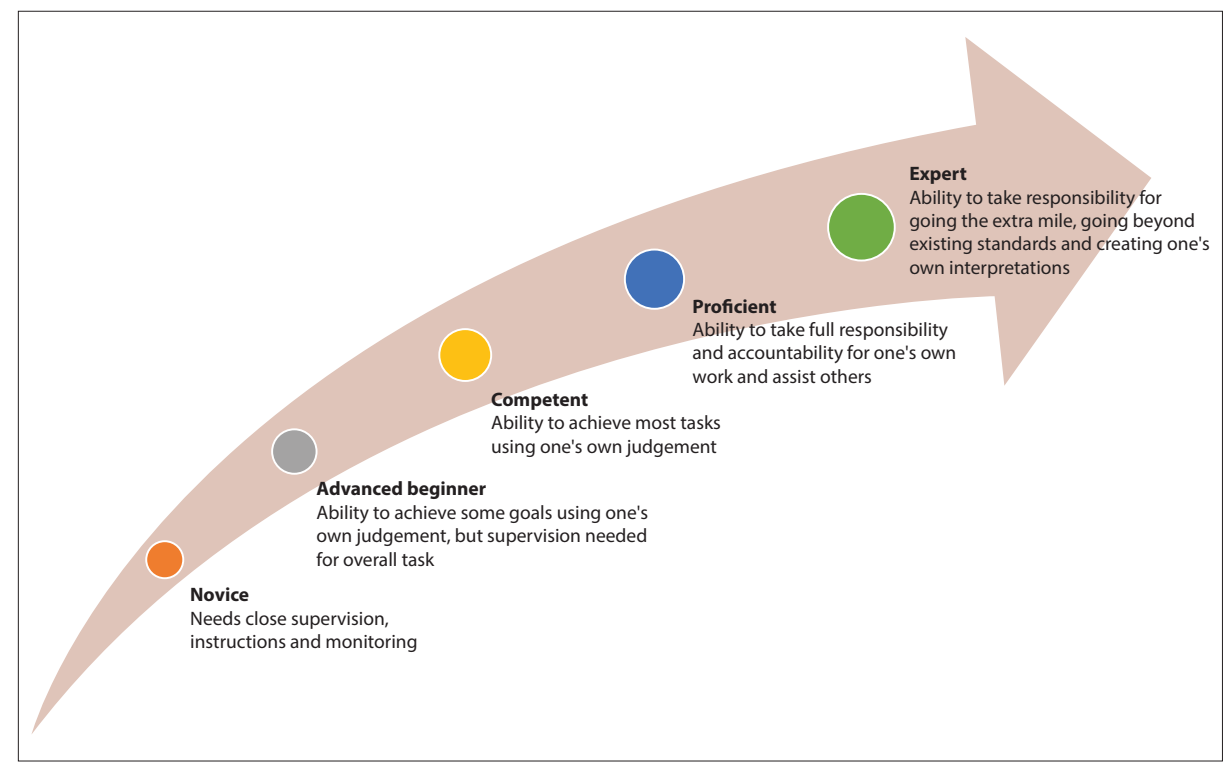

Fig. 1. Figure adapted from Benner's levels of competence. ${ }^{[12]}$ 
data individually, compared the results and agreed to the final themes and sub-themes. The results could not be generalised, but the research process, particularly data collection, is discussed in detail so that any alternative application of this research in a similar context will be possible.

- To ensure confirmability, data were interpreted, whereby themes and sub-themes were supported by quotations to reflect the views of the participants. Confirmability was ensured when the data obtained and the link between the interpretation of results and actual events was supported by discussion of the results, recommendations and conclusions.

- To confirm transferability, data were presented in a descriptive manner so that other researchers could compare data if necessary. Furthermore, the study employed purposive sampling based on the participants' knowledge of the phenomenon and a context deemed appropriate for the study.

\section{Ethical approval}

The Scientific Committee of the School of Nursing Science (SONS) and the Faculty of Agriculture, Science and Technology Health Science Ethics Committee (FAST-HSEC) of North-West University gave ethical approval for this study (ref. no. NWU-00230-18-A9). The North West Department of Health (NWDoH) and the two selected hospitals in NWP granted approval for the study. Informed consent was obtained before commencement of the process, after an explanation of what was expected from the participants. Participants were advised that involvement was voluntary and that they had the right to opt out of the interviews at any stage without providing an explanation and without incurring any penalties, after which they gave their informed consent.

\section{Results}

Four themes emerged from the data analysis. Fig. 2 illustrates the convergence of results.

Tables 1 and 2 represent the first 3 themes that emerged and the levels of competence of PNs and CSNs.

\section{Theme 1: Ethos and professional practice}

The International Council of Nurses (ICN) adopted the first international code of ethics

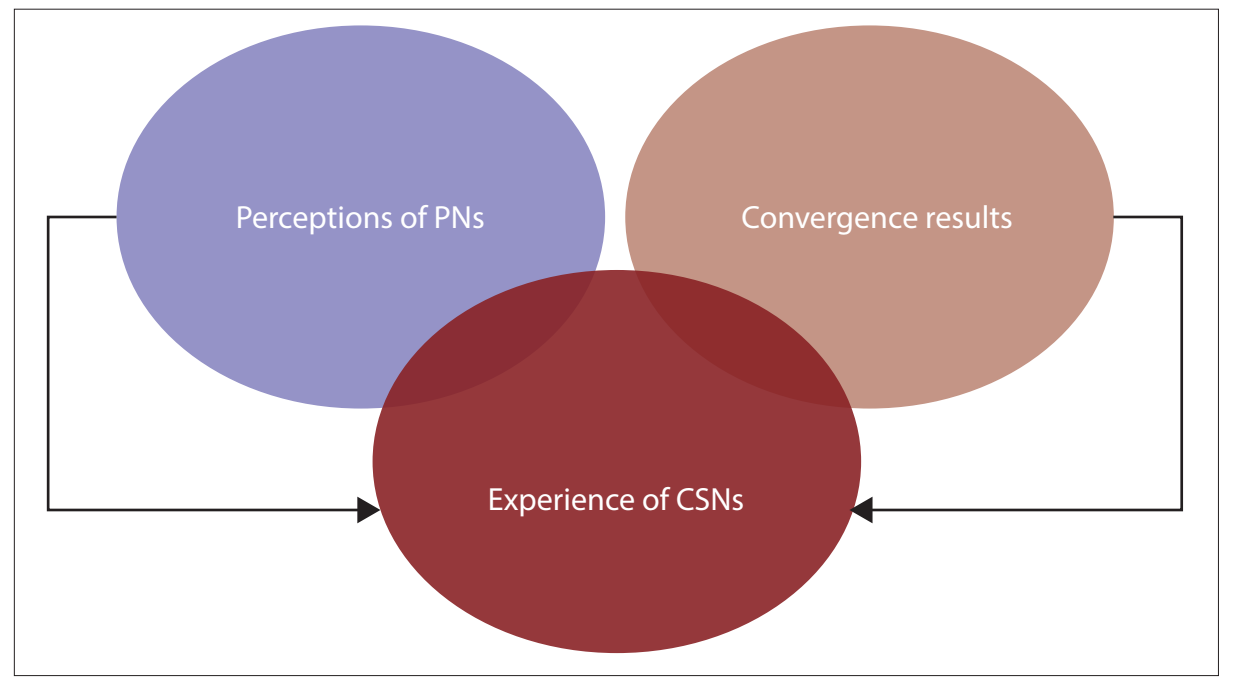

Fig. 2. Convergence of the results. ${ }^{[14]}$ (PNs = professional nurses; CSNs = community service nurses. $)$

for nurses in 1953. Since then, other nursing and midwifery regulatory bodies followed and adopted these codes of ethics. ${ }^{[15]}$ The code of ethics is the cornerstone of ethical decision-making and aimed to inform nursing practitioners and the public of the following ethical and moral principles applicable to nursing practitioners in the performance of their duties. ${ }^{\text {'16] }}$ An 'effective ethical code for nursing practice must provide guidance on managing ethical problems that arise at the societal level, the organisational level, and the clinical level. ${ }^{[17]}$ Therefore, the ethical code summarises ethical behaviour for the nursing profession and guides decision-making when barriers that prevent fulfilment of their professional obligations are encountered. ${ }^{[18]}$ In this study, participants reported that ethos and practice form the basis of the nursing profession, which were in support of those of a study in Iran. ${ }^{[19]}$ Their qualitative study revealed that the majority of nurses highlighted professional ethics and accountability as important characteristics that provided the basis for the ethical context in healthcare settings. ${ }^{[19]}$ Therefore, it is important that CSNs uphold the ethical and professional conduct of the nursing profession. However, the results revealed that CSNs from both hospitals had little knowledge of ethical or professional conduct. This was supported by PNs, who stated that CSNs do not uphold the ethical and professional conduct of the nursing profession, particularly with regard to nursing etiquette. Results from the literature on interpersonal and communication skills revealed that newly qualified nurses are unable to communicate effectively with multidisciplinary team members. ${ }^{[20]}$ In this study, participants mentioned that CSNs face challenges when they should communicate with multidisciplinary team members or when answering the telephone. The outcome of this study also concurred with the results of a study conducted in the USA, ${ }^{[21]}$ which revealed that many challenging experiences with regard to team-member communication were described by new graduate nurses.

In this study, CSNs revealed that they had limited knowledge of ethics, which was a concern, as this could also affect their responsibilities with regard to patient advocacy. According to Tomaschewski-Barlem et al., ${ }^{[22]}$ the nurse-patient relationship, effective communication and recognition of patients' needs are essential for effective advocacy practice. They further maintain that the establishment of a proper relationship with patients enables nurses to understand more broadly the patients' real needs and become more efficacious when defending the desires and interests of their patients.

When considering the upholding of values and principles, including Batho Pele principles and the patient rights charter, the results of this study were in contrast to those of an Iranian study conducted on nurses and student nurses' awareness of patients' rights, ${ }^{[23]}$ which reported that participants were knowledgeable and aware of these rights. Our study showed that CSNs lacked knowledge or application of ethical and professional conduct. 
Table 1. Competence levels of community service nurses (rating scale $\mathrm{A}$ and motivation), group $\mathrm{A}^{[14]}$

\begin{tabular}{|c|c|c|c|c|c|}
\hline \multirow[b]{2}{*}{ Themes } & \multirow[b]{2}{*}{ Sub-themes } & \multicolumn{2}{|c|}{ CSN } & \multicolumn{2}{|c|}{ PN } \\
\hline & & Competence level rating & Motivation & Competence level rating & Motivation \\
\hline $\begin{array}{l}\text { Ethos and } \\
\text { professional practice }\end{array}$ & Ethics in nursing & 2 - advanced beginner & $\begin{array}{l}\text { 'I don't have much } \\
\text { exposure with regard to } \\
\text { ethics' }\end{array}$ & Novice & $\begin{array}{l}\text { 'They do not uphold to the } \\
\text { professional and ethical } \\
\text { conducts of nursing. They } \\
\text { are resistant to adhere to } \\
\text { uniform, no telephone } \\
\text { etiquette' }\end{array}$ \\
\hline \multirow[t]{2}{*}{$\begin{array}{l}\text { Unit management, } \\
\text { governance and } \\
\text { leadership }\end{array}$} & Unit administration & 3 - competent & $\begin{array}{l}\text { 'I had day-to-day } \\
\text { exposure of the wards } \\
\text { and what is expected to } \\
\text { run the ward' }\end{array}$ & 2 - advanced beginner & $\begin{array}{l}\text { 'Application of different } \\
\text { management skills and } \\
\text { personnel management and } \\
\text { communication skills' }\end{array}$ \\
\hline & $\begin{array}{l}\text { Governance and } \\
\text { leadership }\end{array}$ & 3 - competent & $\begin{array}{l}\text { 'I am able to take } \\
\text { leadership and assist } \\
\text { junior students and } \\
\text { personnel who are not } \\
\text { well' }\end{array}$ & 2 - advanced beginner & $\begin{array}{l}\text { 'Do not take responsibility. } \\
\text { They cannot lead' }\end{array}$ \\
\hline \multirow[t]{4}{*}{$\begin{array}{l}\text { Contextual, clinical } \\
\text { and technical } \\
\text { competence }\end{array}$} & $\begin{array}{l}\text { Medical/surgical } \\
\text { nursing }\end{array}$ & 3 - competent & $\begin{array}{l}\text { 'I have knowledge as I } \\
\text { worked there during my } \\
\text { studies and I can carry } \\
\text { out tasks and run the } \\
\text { unit' }\end{array}$ & 3 - competent & $\begin{array}{l}\text { 'They [CSNs] are } \\
\text { competent but still need } \\
\text { minimal supervision' }\end{array}$ \\
\hline & Midwifery nursing & 2 - advanced beginner & $\begin{array}{l}\text { 'I am able to apply } \\
\text { maternity guidelines to } \\
\text { manage patients' }\end{array}$ & 1 - novice & $\begin{array}{l}\text { 'Some still need intense } \\
\text { supervision' }\end{array}$ \\
\hline & $\begin{array}{l}\text { Psychiatric/mental } \\
\text { health nursing }\end{array}$ & 2 - advanced beginner & $\begin{array}{l}\text { 'I had little time at } \\
\text { the unit, but with } \\
\text { knowledge of practical, I } \\
\text { can achieve some goals' }\end{array}$ & 1 - novice & $\begin{array}{l}\text { 'They cannot be rated as } \\
\text { competent because there } \\
\text { is no psychiatric unit, } \\
\text { patients are admitted } \\
\text { for observation, so the } \\
\text { exposure for learning is } \\
\text { limited' }\end{array}$ \\
\hline & Operating theatre & 1 - novice & $\begin{array}{l}\text { 'I have never worked } \\
\text { there' }\end{array}$ & 1 - novice & $\begin{array}{l}\text { 'Their exposure is limited } \\
\text { in their training and the } \\
\text { area is highly specialised } \\
\text { with a lot of risks' }\end{array}$ \\
\hline
\end{tabular}

\section{Theme 2: Unit management, governance and leadership}

Participants reported that some CSNs had the ability to manage the unit with minimal supervision. However, the majority of PNs disagreed, as some CSNs mentioned that they had never been in a situation where they led or managed a unit, and therefore were not confident regarding their leadership skills. These results concurred with an SA study, where CSNs where unable to manage conflicts, and expressed reluctance to take the lead, particularly with delegation of duties and other managerial responsibilities. ${ }^{[24]}$

\section{Theme 3: Contextual clinical and technical competence}

The study by Walker et al. ${ }^{[25]}$ established that new graduate nurses work in challenging healthcare environments with unfamiliar technologies, work shift hours, heavy patient loads, and have to deal with patient safety issues. In this study, participants reported that contextual clinical and technical competence was not satisfactory; this competence was dependent on the time spent in specifically allocated units. It was also reported that some CSNs need supervision on basic procedures, such as management of a patient receiving a blood transfusion and delegation of duties, and that there is a lack of adequate exposure during their training.

\section{Study limitations}

The researchers acknowledge that this qualitative research is limited to only two NWP hospitals in SA and that the results cannot be generalised. However, the study delivers important information and confirmation that can be considered by CSNs and PNs, as well as other stakeholders, including hospital management and the $\mathrm{NWDoH}$, for measures to improve clinical competence of CSNs during their community service placements.

\section{Recommendations}

- There is a dire need to improve the ethical and professional conduct 
Table 2. Competence levels of community service nurses (rating scale $\mathbf{A}$ and motivation), group $\mathbf{B}^{[14]}$

\begin{tabular}{|c|c|c|c|c|c|}
\hline \multirow[b]{2}{*}{ Themes } & \multirow[b]{2}{*}{ Sub-themes } & \multicolumn{2}{|c|}{ CSN } & \multicolumn{2}{|c|}{ PN } \\
\hline & & Competence level rating & Motivation & Competence level rating & Motivation \\
\hline $\begin{array}{l}\text { Ethos and professional } \\
\text { practice }\end{array}$ & Ethics in nursing & 2 - advanced beginner & $\begin{array}{l}\text { 'Not really clued } \\
\text { up much on ethical } \\
\text { principles in nursing' }\end{array}$ & 2 - advanced beginner & $\begin{array}{l}\text { 'Their behaviour must still } \\
\text { improve' }\end{array}$ \\
\hline \multirow[t]{2}{*}{$\begin{array}{l}\text { Unit management, } \\
\text { governance and } \\
\text { leadership }\end{array}$} & Unit administration & 2 - advanced beginner & $\begin{array}{l}\text { 'Have not had much } \\
\text { chance to run a unit, but } \\
\text { I have been trained on } \\
\text { how to' }\end{array}$ & 3 - competent & $\begin{array}{l}\text { 'Ability to manage the ward } \\
\text { under indirect supervision' }\end{array}$ \\
\hline & $\begin{array}{l}\text { Governance and } \\
\text { leadership }\end{array}$ & 1 - novice & $\begin{array}{l}\text { 'Never came across a } \\
\text { situation where I have to } \\
\text { lead people' }\end{array}$ & 1 - novice & $\begin{array}{l}\text { 'Not enough exposure to } \\
\text { lead in the unit' }\end{array}$ \\
\hline \multirow[t]{4}{*}{$\begin{array}{l}\text { Contextual, clinical } \\
\text { and technical } \\
\text { competence }\end{array}$} & $\begin{array}{l}\text { Medical/surgical } \\
\text { nursing }\end{array}$ & 3 - competent & $\begin{array}{l}\text { 'I've worked in this unit } \\
\text { most of my training, I } \\
\text { can handle them pretty } \\
\text { well by myself' }\end{array}$ & 3 - competent & $\begin{array}{l}\text { 'With multiple conditions, } \\
\text { some appear less often than } \\
\text { others; they [CSNs] are } \\
\text { competent' }\end{array}$ \\
\hline & Midwifery nursing & 3 - competent & $\begin{array}{l}\text { 'I can manage a pregnant } \\
\text { woman from antenatal } \\
\text { care to puerperium' }\end{array}$ & 2 - advanced beginner & $\begin{array}{l}\text { 'Due to limited exposure, } \\
\text { supervision is still } \\
\text { necessary in the working } \\
\text { environment' }\end{array}$ \\
\hline & $\begin{array}{l}\text { Psychiatric/mental } \\
\text { health nursing }\end{array}$ & 2 - advanced beginner & $\begin{array}{l}\text { 'I still need supervision } \\
\text { on almost everything I } \\
\text { am doing' }\end{array}$ & 2 - advanced beginner & $\begin{array}{l}\text { 'Certain situations they } \\
\text { [CSNs] have not come } \\
\text { across. So supervision is } \\
\text { really needed' }\end{array}$ \\
\hline & Operating theatre & 2 - advanced beginner & $\begin{array}{l}\text { 'I did not have enough } \\
\text { clinical exposure' }\end{array}$ & 2 - advanced beginner & $\begin{array}{l}\text { 'They do not get to be } \\
\text { allocated in theatre unit for } \\
\text { enough hours' }\end{array}$ \\
\hline
\end{tabular}

of CSNs. Strategies include in-service training and staff workshops on topics related to ethical and professional practice to be incorporated into teaching at each unit to which CSNs are allocated. This should be reinforced on rotation of CSNs to new units.

- Orientation and induction programmes must provide relevant information and focus on ensuring overall competence in the specific unit to which a CSN is assigned.

- Supervision and mentorship programmes at different units are recommended.

- The allocation and rotation period for CSNs must be carried out in a manner that includes the majority of the disciplines, which will assist CSNs with exposure opportunities.

- Providing CSNs with opportunities to take charge of the unit through the delegation of management duties will boost their confidence in unit management and leadership.

\section{Conclusion}

It was deemed necessary to report convergence of the results because of similarities identified in the outcomes of the World Café discussions on the perceptions of PNs and CSNs regarding clinical competence during community service placement. Utilisation of the World Café method allowed for real conversations on mutual topics of interest, and the rich data collected is an accurate expression of the participants' perceptions and experiences. These results contributed to the development of a tool to evaluate clinical competence of CSNs in NWP.

\section{Declaration. None.}

Acknowledgements. The researchers acknowledge the research assistants for their assistance with data collection and the participants for taking part in this study. Author contributions. KLM was responsible for finalisation of data analysis and writing of the manuscript. LAS was responsible for conceptualisation and proofreading of the manuscript. AJP finalised the data collection, analysed the collected data and made conceptual contributions to the manuscript.

Funding. The Health and Welfare Sector Education and Training Authority (HWSETA) and North-West University, Mahikeng campus, provided financial support to conduct the main study.

Conflicts of interest. None.

\footnotetext{
1. Edwards D, Hawker C, Carrier J, Rees C. A systematic review of the effectiveness of strategies and interventions to improve the transition from student to newly qualified nurse. Int J Nurs Stud 2015;52(7):1254 -1268. https: doi.org/10.1016/.jijnurstu.2015.03.007

2. Fernandez R, Sheppard-Law S, Curtis S, Bancroft J, Smith W. Exploring the experiences of neophyte nurse mentors: A qualitative study. Nurse Educ Pract 2018;29:76-81. https://doi.org/10.1016/j.nepr.2017.11.011

3. National Department of Health. Health on community service by health professionals. 2006. https://www.gov.za/ health-community-service-health-professionals (accessed 15 May 2020).

4. South African Nursing Council. Regulations: Community Service Regulation No. R765 of 2007.

5. National Department of Health. Nursing Act, 2005 (Act No. 33 of 2005). Government Gazette No. 34852. 2011.

6. Adu-Gyamfi S, Edward B. Nursing in Ghana: A search for Florence Nightingale in an African city. Int Scholar Res 6. Adu-Gyamfi S, Edward B. Nursing in Ghana: A search for Floren
Notices 2016;2016:1-14. https://doi.org/10.1155/2016/9754845

7. Wilkes 2016;2016:1-14. https://doi.org/10.1155/2016/9754845 2013;44(1):31-37. https://doi.org/10.3928/00220124-20121101-53

8. Polit DF, Beck CT. Nursing Research: Generating and Assessing Evidence for Nursing Practice. 10th ed. London Lippincott Williams and Wilkins, 2017

9. Van Wyngaarden A, Leech R, Coetzee IM. Assessing the value of action research: Using World Café to explore the professional journey of nurse educators. S Afr J Higher Educ 2018;6:519-531. https://doi.org/10.20853/326-2974.32

10. Froneman K, du Plessis E, Koen M. Effective educator-student relationships in nursing education to strengthen nursing students' resilience. Curationis 2016;39(1):a1595. https://doi.org/10.4102/curationis.v39i1.1595
} 
11. Benner P. From Novice to Expert: Excellence and Power in Clinical Nursing Practice. New Jersey: PrenticeHall, 1984.

12. Pienaar AJ. Learning and asserting an African indigenous health research framework. In: Ngulube P, ed. Handbook of Research on Theoretical Perspectives on Indigenous Knowledge Systems in Developin Countries. Pennsylvania: IGI Global, 2017:85-99.

13. Creswell JW, Creswell JD. Research Design: Qualitative, Quantitative and Mixed Methods Approaches. 5th ed. Los Angeles, SAGE, 2018.

Mathaba KL. Development of an evaluation tool for clinical competence of community service nurses in North West Province, South Africa. PhD thesis. Mahikeng: North-West University, 2019.

15. International Council of Nurses. The ICN code of ethics for nurses. 2012. ethics.iit.edu/ecodes/sites/default files/International\%20Council $\% 20$ of $\% 20$ Nurses\%20Code $\% 20$ of $\% 20$ Ethics $\% 20$ for $\% 20$ Nurses.pdf (accesse 15 May 2020).

16. South African Nursing Council. Code of ethics for nursing practitioners in South Africa. 2013. https://www sanc.co.za/pdf/Learner\%20docs/SANC\%20Code\%20 of\%20Ethics\%20for\%20Nursing $\% 20$ in $\% 20$ South\%20 Africa.pdf (accessed 15 May 2020).

17. Epstein B, Turner M. The nursing code of ethics: Its value, its history. Online J Issues Nurs 2015;20(2). https:// doi.org/10.3912/OJIN.Vol20No02Man04

18. Zahedi F, Sanjari M, Aala M, et al. The code of ethics for nurses. Iran J Public Health 2013;42(Suppl 1):1-8.

19. Dehghani A, Mosalanejad L, Dehghan-Nayeri N. Factors affecting professional ethics in nursing practice in Iran: A qualitative study. BMC Med Ethics 2015;16(61):1-7. https://doi.org/10.1186/s12910-015-0048-2
20. Phillips C, Esterman A, Kenny A. The theory of organizational socialisation and its potential for improving transition experiences for new graduate nurses. Nurse Educ Today 2015:35(1):118e-124e. https://dol org/10.1016/j.nedt.2014.07.011

1. Ortiz J. New graduate nurses' experiences about lack of professional confidence. Nurse Educ Pract 2016;19:19-24 https://doi.org/10.1016/j.nepr.2016.04.001

22. Tomaschewski-Barlem JG, Lunardi VL, Barlem ELD, et al. Patient advocacy in nursing: Barriers, facilitator and potential implications. Texto Contexto-Enfermagem 2017;26(3):e0100014. https://doi.org/10.1590/010 0707201700010001

3. Heidari A, Ahmadpour Z, Ghareh Boughlou Z. Patients' and nurses' awareness of patients rights: A comparative study. Health Spiritual Med Ethics 2014;1(1):2-8.

24. Ndaba BJ, Nkosi ZZ. Lived experiences of newly qualified professional nurses on community service in midwifery section. Afr J Phys Health Educ Recreat Dance 2015;21(4-10):1150-1160.

25. Walker A, Earl C, Costa B, Cuddihy L. Graduate nurses' transition and integration into the workplace: A qualitative comparison of graduate nurses' and nurse unit managers' perspectives. Nurse Educ Today 2013;33(3):291-296. https://doi.org/10.1016/.nedt.2012.06.005

Accepted 7 September 2020 